\title{
Cleavage of the Ge-S and $\mathrm{C}-\mathrm{H}$ bonds in the reaction of electron-deficient $\left[\mathrm{Os}_{3}(\mathrm{CO})_{8}(\mu-\mathrm{H})\left(\mu_{3}-\mathrm{Ph}_{2} \mathrm{PCH}_{2} \mathrm{P}(\mathrm{Ph}) \mathrm{C}_{6} \mathrm{H}_{4}\right)\right]$ with $\mathrm{Ph}_{3} \mathrm{GeSPh}$ : Generation of thiophenol derivatives $\left[\mathrm{Os}_{3}(\mathrm{CO})_{8}(\mu-\mathrm{H})(\mu-\mathrm{SPh})(\mu-\mathrm{dppm})\right] \quad$ and $\left[\left(\mathrm{Os}_{3}(\mathrm{CO})_{7}(\mu-\mathrm{H})(\mu-\mathrm{SPh})\left(\mu_{3}-\mathrm{SC}_{6} \mathrm{H}_{4}\right)(\mu-\mathrm{dppm})\right]\right.$
}

\author{
Arun K. Raha ${ }^{(1)}$, Shishir Ghosh ${ }^{(1)}$, Shariff E. Kabir ${ }^{(1), *}$, Brian K. Nicholson ${ }^{(2)}$, Derek A. \\ Tocher $^{(3)}$ \\ ${ }^{(1)}$ Department of Chemistry, Jahangirnagar University, Savar, Dhaka-1342, Bangladesh \\ ${ }^{(2)}$ Department of Chemistry, University of Waikato, Hamilton, New Zealand \\ ${ }^{(3)}$ Department of Chemistry, University College London, 20 Gordon Street, London WC1H \\ OAJ, UK \\ * To whom correspondence should be addressed: skabir_ju@yahoo.com
}

\begin{abstract}
Heating the electron-deficient $\left[\mathrm{Os}_{3}(\mathrm{CO})_{8}(\mu-\mathrm{H})\left(\mu_{3}-\mathrm{Ph}_{2} \mathrm{PCH}_{2} \mathrm{P}(\mathrm{Ph}) \mathrm{C}_{6} \mathrm{H}_{4}\right)\right](\mathbf{1})$ and $\mathrm{Ph}_{3} \mathrm{GeSPh}$ in benzene at $80{ }^{\circ} \mathrm{C}$ led to the thiolato bridged compounds, $\mathrm{OS}_{3}(\mathrm{CO})_{8}(\mu-\mathrm{H})(\mu-\mathrm{SPh})(\mu$ dppm) $]$ (2) and $\left[\left(\mathrm{Os}_{3}(\mathrm{CO})_{7}(\mu-\mathrm{H})(\mu-\mathrm{SPh})\left(\mu_{3}-\mathrm{SC}_{6} \mathrm{H}_{4}\right)(\mu-\mathrm{dppm})\right](3)\right.$, formed by cleavage of Ge-S and C-S bond cleavage of the ligand, in 40 and $17 \%$ yields, respectively. Both compounds $\mathbf{2}$ and $\mathbf{3}$ have been characterized by a combination of elemental analysis, infrared and ${ }^{1} \mathrm{H}$ NMR spectroscopic data together with single crystal X-ray crystallography. Compound 2 crystallizes in the triclinic space group $P-1$ with $a=11.5072(8), b=$ 12.3475(8), $c=15.1330(10) \AA, \beta=98.894(1)^{\circ}, Z=4$ and $V=5105.07(14) \AA^{3}$ and 3 crystallizes in the monoclinic space group $P 2_{1} / n$ with $a=9.9678(2), b=28.0191(2), c=$ 18.5013(3) $\AA, \beta=98.894(1)^{\circ}, \mathrm{Z}=4$ and $V=5105.07(14) \AA^{3}$. Compound 3 contains an open triangle of osmium atoms bridged by a $\mathrm{SPh}$ and $\mathrm{SC}_{6} \mathrm{H}_{4}$ ligands on opposite sides of the cluster with a dppm ligand bridging one of the Os-Os edges. Compound 2 consists of a closed triangular cluster of osmium atoms with a bridging $\mathrm{SPh}$, and a bridging hydride ligand on the same Os-Os edge, and a dppm ligand bridging one of the remaining Os-Os edges.
\end{abstract}

KEY WORDS: Triosmium clusters; bond cleavage (Ge-S, C-H); thiophenol; dppm; X-ray structures. 


\section{Introduction}

The electron-deficient triosmium cluster $\left[\mathrm{Os}_{3}(\mathrm{CO})_{8}(\mu-\mathrm{H})\left(\mu_{3}-\mathrm{Ph}_{2} \mathrm{PCH}_{2} \mathrm{P}(\mathrm{Ph}) \mathrm{C}_{6} \mathrm{H}_{4}\right)\right]$ (1) derived from the decarbonylation of the decacarbonyl compound $\left[\mathrm{Os}_{3}(\mathrm{CO})_{10}(\mu\right.$-dppm) $]$ has attracted considerable interest for many years and its chemistry has been thoroughly investigated during the last decade to reveal its catalytic potential as well as applications in organic synthesis. $^{1-15}$ Electron-deficiency in $\mathbf{1}$ makes it more vulnerable to attack by nucleophiles and practically it reacts with a wide range of electron donor ligands under mild conditions relative to electron precise complexes.
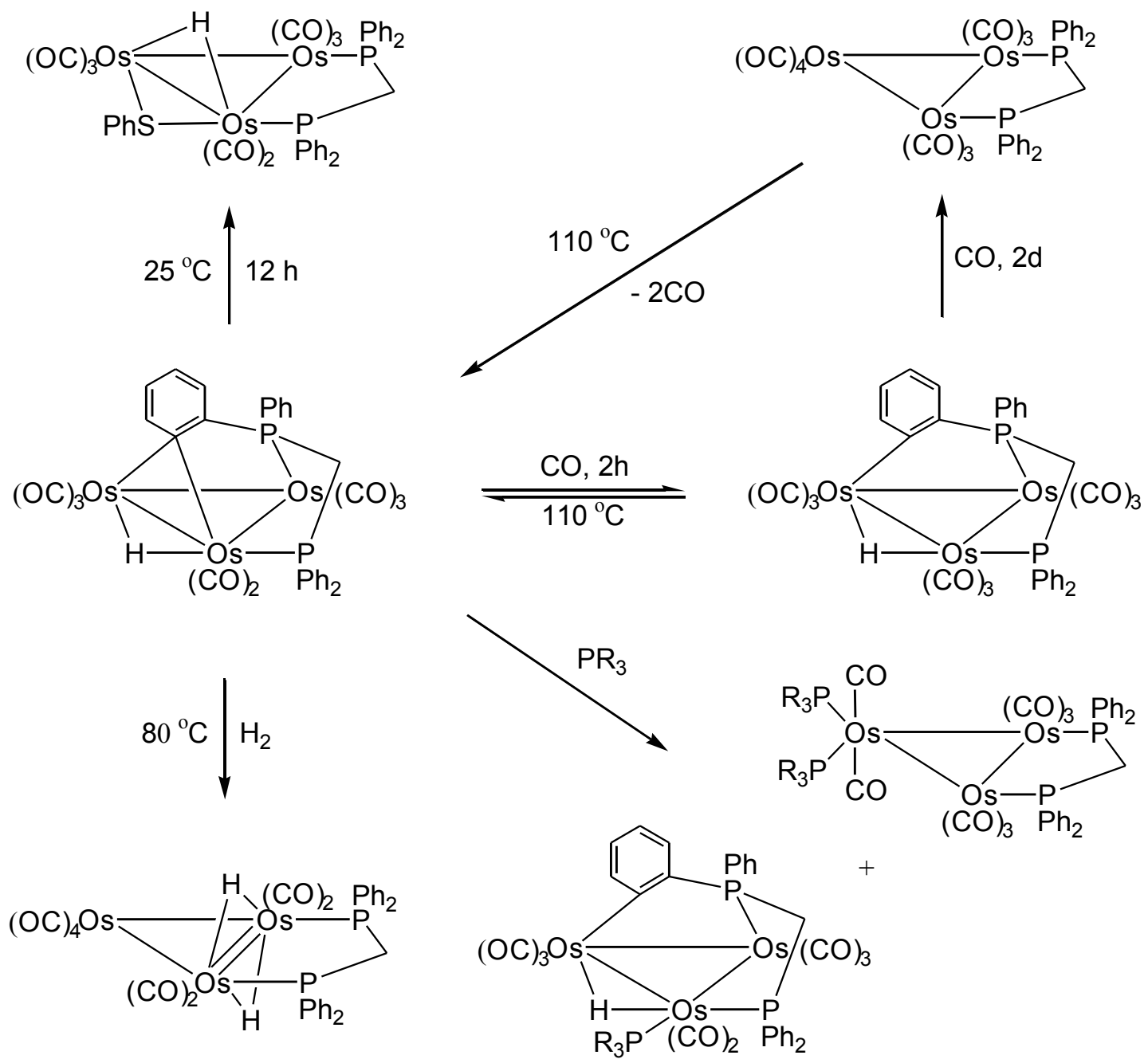

\section{Scheme 1.}


The reactions 1 with a wide variety of small inorganic and organic ligands such as $\mathrm{CO},{ }^{4} \mathrm{H}_{2},{ }^{5} \mathrm{PR}_{3},{ }^{6} \mathrm{P}(\mathrm{OR})_{3}\left(\mathrm{R}=\mathrm{Me}, \mathrm{Et}, \mathrm{Pr}^{\mathrm{i}}, \mathrm{Bu}, \mathrm{Ph}\right),{ }^{6} \mathrm{PPh}_{2} \mathrm{H},{ }^{7} \mathrm{RC} \equiv \mathrm{CR}\left(\mathrm{R}=\mathrm{Ph}, \mathrm{C}_{6} \mathrm{H}_{4} \mathrm{Me}, \mathrm{Me}\right.$, $\left.\mathrm{CF}_{3}\right),{ }^{8}\left[\mathrm{Au}\left(\mathrm{PPh}_{3}\right)\right] \mathrm{PF}_{6},{ }^{9} \mathrm{EtSH},{ }^{10} \mathrm{CH}_{3} \mathrm{CH}\left(\mathrm{CH}_{3}\right) \mathrm{SH}^{10}{ }^{10} \mathrm{PhSH}^{10}{ }^{10} \mathrm{pySH}^{11}{ }^{11} \mathrm{HSCH}_{2} \mathrm{CH}_{2} \mathrm{SH},{ }^{12}$ $\mathrm{HSCH}_{2} \mathrm{CH}_{2} \mathrm{CH}_{2} \mathrm{SH},{ }^{12} \mathrm{Se},{ }^{13} \mathrm{HX}\left(\mathrm{X}=\mathrm{Cl}, \mathrm{Br}, \mathrm{F}, \mathrm{CF}_{3} \mathrm{CO}_{2}, \mathrm{CH}_{3} \mathrm{CO}_{2}\right),{ }^{14} \mathrm{CH}_{2} \mathrm{CN}_{2},{ }^{15}$ silane ${ }^{16}$ and $\mathrm{Ph}_{3} \mathrm{SnH}^{17}$ that afford many interesting and potentially useful compounds have been investigated (Scheme 1). We have recently reported some unusual bimetallic $\mathrm{Ru}-\mathrm{Sn}, \mathrm{Ru}-\mathrm{Ge}$ clusters, e,g. $\quad\left[\mathrm{Ru}_{3}(\mathrm{CO})_{8}(\mu-\mathrm{SPh})_{2}\left(\mu_{3}-\mathrm{SnPh}_{2}\right)\left(\mathrm{SnPh}_{3}\right)_{2}\right] \quad$ and $\quad\left[\mathrm{Ru}_{3}(\mathrm{CO})_{8}(\mu-\mathrm{SPh})_{2}\left(\mu_{3^{-}}\right.\right.$ $\left.\left.\mathrm{GePh}_{2}\right)\left(\mathrm{GePh}_{3}\right)_{2}\right]$, from the reactions of $\mathrm{Ph}_{3} \mathrm{SnSPh}$ and $\mathrm{Ph}_{3} \mathrm{GeSPh}$ with $\left[\mathrm{Ru}_{3}(\mathrm{CO})_{12}\right]$, respectively. ${ }^{18}$ We also reported the Os-Sn compound $\left[\mathrm{Os}_{3}(\mathrm{CO})_{9}(\mu-\mathrm{SPh})\left(\mu_{3-}\right.\right.$ $\left.\left.\mathrm{SnPh}_{2}\right)(\mathrm{NCMe})\left(\eta^{1}-\mathrm{C}_{6} \mathrm{H}_{5}\right)_{2}\right]$ from the reaction of $\left[\mathrm{Os}_{3}(\mathrm{CO})_{10}(\mathrm{NCMe})_{2}\right]$ with $\mathrm{Ph}_{3} \mathrm{SnSPh}$.

As a part of our work on going studies on bimetallic Os-Ge clusters, we set out to investigate the reactivity of the electron-deficient 1 with $\mathrm{Ph}_{3} \mathrm{GeSPh}$. Unfortunately, the reaction does not appear to give any Os-Ge product, instead only the thiolato part of the ligand incorporated into the cluster resulting in the formation of $\left[\mathrm{Os}_{3}(\mathrm{CO})_{8}(\mu-\mathrm{H})(\mu-\mathrm{SPh})(\mu-\right.$ dppm) $]$ (2) and $\left[\left(\mathrm{Os}_{3}(\mathrm{CO})_{7}(\mu-\mathrm{H})(\mu-\mathrm{SPh})\left(\mu_{3}-\mathrm{SC}_{6} \mathrm{H}_{4}\right)(\mu\right.\right.$-dppm) $)$ (3).

\section{Experimental}

All the reactions were performed under a nitrogen atmosphere using standard Schlenk techniques. Solvents were dried and distilled prior to use by standard methods. The starting complex $\left[\mathrm{Os}_{3}(\mathrm{CO})_{8}(\mu-\mathrm{H})\left(\mu_{3}-\mathrm{Ph}_{2} \mathrm{PCH}_{2} \mathrm{P}(\mathrm{Ph}) \mathrm{C}_{6} \mathrm{H}_{4}\right)\right]$ (1) and the ligand $\mathrm{Ph}_{3} \mathrm{GeSPh}$ were prepared according to published procedures. ${ }^{4,19}$ Infrared spectra were recorded on a Shimadzu FTIR 8101 spectrophotometer. ${ }^{1} \mathrm{H}$ NMR spectra were recorded on a Bruker DPX 400 spectrometer. Elemental analyses were performed by Microanalytical Laboratories, University College London. Fast atom bombardment mass spectra were obtained on a JEOLSX-102 spectrometer using 3-nitrobenzyl alcohol as matrix and CsI as calibrant.

\section{Reaction of $\left[\mathrm{Os}_{3}(\mathrm{CO})_{8}(\mu-\mathrm{H})\left(\mu_{3}-\mathrm{Ph}_{2} \mathrm{PCH}_{2} \mathrm{P}(\mathrm{Ph}) \mathrm{C}_{6} \mathrm{H}_{4}\right)\right]$ (1) with $\mathrm{Ph}_{3} \mathrm{GeSPh}$}

A benzene $(20 \mathrm{~mL})$ solution of $1(50 \mathrm{mg}, 0.042 \mathrm{mmol})$ and $\mathrm{Ph}_{3} \mathrm{GeSPh}(35 \mathrm{mg}, 0.084$ mmol) was heated to reflux for $9 \mathrm{~h}$ during which time the color changed from green to yellow. The progress of the reaction was followed by spot TLC. The solvent was removed under reduced pressure and the residue chromatographed by TLC on silica gel. Elution with hexane $/ \mathrm{CH}_{2} \mathrm{Cl}_{2}(7: 3, \mathrm{v} / \mathrm{v})$ developed three bands. The second band gave the unreacted 
starting compound $1(6 \mathrm{mg})$ while the first and third bands afforded $\left[\mathrm{Os}_{3}(\mathrm{CO})_{8}(\mu-\mathrm{H})(\mu-\right.$ $\mathrm{SPh})\left(\mu\right.$-dppm)] (2) (22 mg, 40\%) as orange crystals and $\left[\left(\mathrm{Os}_{3}(\mathrm{CO})_{7}(\mu-\mathrm{H})(\mu-\mathrm{SPh})\left(\mu_{3}-\right.\right.\right.$ $\left.\mathrm{SC}_{6} \mathrm{H}_{4}\right)(\mu$-dppm)] (3) $(10 \mathrm{mg}, 17 \%)$ as pale yellow crystals after recrystallization from hexane/ $\mathrm{CH}_{2} \mathrm{Cl}_{2}$ at $4{ }^{\circ} \mathrm{C}$. Spectral data for 2: Anal. Calcd. for $\mathrm{C}_{39} \mathrm{H}_{28} \mathrm{O}_{8} \mathrm{Os}_{3} \mathrm{P}_{2} \mathrm{~S}: \mathrm{C}, 36.33 ; \mathrm{H}$, 2.19. Found: C, 36.55; H, 2.23\%. IR ( $\left.v \mathrm{CO}, \mathrm{CH}_{2} \mathrm{Cl}_{2}\right)$ : 2067 vs, $2023 \mathrm{~m}, 1993$ vs, $1970 \mathrm{~m}$, $1955 \mathrm{~m}, 1923 \mathrm{w} \mathrm{cm}^{-1} .{ }^{1} \mathrm{H}$ NMR $\left(\mathrm{CDCl}_{3}\right): \delta 7.66(\mathrm{~m}, 2 \mathrm{H}), 7.53(\mathrm{~m}, 3 \mathrm{H}), 7.42(\mathrm{~m}, 5 \mathrm{H}), 7.32$ (m, 6H), $7.13(\mathrm{~m}, 9 \mathrm{H}), 5.73(\mathrm{dd}, 1 \mathrm{H}, J=24.2,12.5 \mathrm{~Hz}), 4.56(\mathrm{dd}, 1 \mathrm{H}, J=24.2,12.5 \mathrm{~Hz})$, $-15.76(\mathrm{~d}, 1 \mathrm{H}, J=29.6 \mathrm{~Hz}) .{ }^{31} \mathrm{P}-\left\{{ }^{1} \mathrm{H}\right\} \mathrm{NMR}\left(\mathrm{CDCl}_{3}\right): \delta-24.1$ (br, s), -24.8 (br, s). FAB mass spectrum: m/z $1290\left(\mathrm{M}^{+}\right), 1262\left(\mathrm{M}^{+}-\mathrm{CO}\right), 1234\left(\mathrm{M}^{+}-2 \mathrm{CO}\right), 1206\left(\mathrm{M}^{+}-3 \mathrm{CO}\right), 1178$ ( $\left.\mathrm{M}^{+}-4 \mathrm{CO}\right), 1150\left(\mathrm{M}^{+}-5 \mathrm{CO}\right), 1122\left(\mathrm{M}^{+}-6 \mathrm{CO}\right), 1094$ ( $\left.\mathrm{M}^{+}-7 \mathrm{CO}\right), 1066$ (M+8CO). Spectral data for 3: Anal. Calcd. For $\mathrm{C}_{44} \mathrm{H}_{32} \mathrm{O}_{7} \mathrm{Os}_{3} \mathrm{P}_{2} \mathrm{~S}_{2}$ : C, 38.59; H, 2.36. Found: C, 38.73; H, 2.41\%. IR ( $\left.v \mathrm{CO}, \mathrm{CH}_{2} \mathrm{Cl}_{2}\right): 2056$ s, 2041 vs, 1996 s, 1983 vs, $1953 \mathrm{w}, 1940 \mathrm{w} \mathrm{cm}{ }^{-1} .{ }^{1} \mathrm{H}$ $\operatorname{NMR}\left(\mathrm{CDCl}_{3}\right): \delta 7.83(\mathrm{dd}, 1 \mathrm{H}, J=6.8,3.6 \mathrm{~Hz}), 7.64(\mathrm{dd}, 1 \mathrm{H}, J=6.0,3.6 \mathrm{~Hz}), 7.58(\mathrm{~m}, 3 \mathrm{H})$, $7.38(\mathrm{~m}, 8 \mathrm{H}), 7.26(\mathrm{~m}, 3 \mathrm{H}), 7.12(\mathrm{~m}, 5 \mathrm{H}), 6.90(\mathrm{~m}, 6 \mathrm{H}), 6.72(\mathrm{~m}, 2 \mathrm{H}), 2.97(\mathrm{~m}, 1 \mathrm{H}), 1.58$ $(\mathrm{m}, 1 \mathrm{H}),-15.66(\mathrm{t}, 1 \mathrm{H}, J=7.2 \mathrm{~Hz}) .{ }^{31} \mathrm{P}-\left\{{ }^{1} \mathrm{H}\right\} \mathrm{NMR}\left(\mathrm{CDCl}_{3}\right): \delta 17.2(\mathrm{~d}, J=94.8 \mathrm{~Hz}), 21.3$ $(\mathrm{d}, J=94.8 \mathrm{~Hz})$. FAB mass spectrum: $\mathrm{m} / \mathrm{z} 1370\left(\mathrm{M}^{+}\right), 1342\left(\mathrm{M}^{+}-\mathrm{CO}\right), 1314\left(\mathrm{M}^{+}-2 \mathrm{CO}\right)$, $1286\left(\mathrm{M}^{+}-3 \mathrm{CO}\right), 1258\left(\mathrm{M}^{+}-4 \mathrm{CO}\right), 1230\left(\mathrm{M}^{+}-5 \mathrm{CO}\right), 1202\left(\mathrm{M}^{+}-6 \mathrm{CO}\right), 1174\left(\mathrm{M}^{+}-7 \mathrm{CO}\right)$.

\section{X-ray crystallography}

Single crystals were mounted on fibres and diffraction data collected at low temperatures (see Table 1) on Bruker AXS SMART APEX CCD diffractometers using Mo$\mathrm{K} \alpha$ radiation $(\lambda=0.71073 \AA)$. Data collection, indexing and initial cell refinements were all done using SMART ${ }^{20}$ software. Data reduction was done with SAINT ${ }^{21}$ software and the SADABS program ${ }^{22}$ was used to apply empirical absorption corrections. The structures were solved by direct methods ${ }^{23}$ and refined by full matrix least-squares on $F^{2}{ }^{24}$ All nonhydrogen atoms were refined anisotropically and hydrogen atoms were included using a riding model. Scattering factors were taken from International Tables for X-ray Crystallography. ${ }^{25}$ All pertinent crystal data and other experimental conditions and refinement details are summarized in Table 1.

\section{Results and discussion}

Reaction of $\left[\mathrm{Os}_{3}(\mathrm{CO})_{8}(\mu-\mathrm{H})\left(\mu_{3}-\mathrm{Ph}_{2} \mathrm{PCH}_{2} \mathrm{P}(\mathrm{Ph}) \mathrm{C}_{6} \mathrm{H}_{4}\right)\right]$ (1) with $\mathrm{Ph}_{3} \mathrm{GeSPh}$ in refluxing benzene for $9 \mathrm{~h}$ resulted in the isolation of two triosmium compounds, $\left[\mathrm{Os}_{3}(\mathrm{CO})_{8}(\mu-\mathrm{H})(\mu-\right.$ 
$\mathrm{SPh})(\mu$-dppm) $]$ (2) and $\left[\left(\mathrm{Os}_{3}(\mathrm{CO})_{7}(\mu-\mathrm{H})(\mu-\mathrm{SPh})\left(\mu_{3}-\mathrm{SC}_{6} \mathrm{H}_{4}\right)(\mu\right.\right.$-dppm) $)(3)$ in 40 and 17\% yields, respectively (Scheme 2). Compound 2 was previously reported from the reactions of thiophenol with $\left[\mathrm{Os}_{3}(\mathrm{CO})_{9}(\mathrm{NCMe})(\mu \text {-dppm) }]^{26}\right.$ and $\mathbf{1}^{10}$ at ambient temperature and with $\left[\mathrm{Os}_{3}(\mathrm{CO})_{10}(\mu-\mathrm{dppm})\right]^{27}$ at $110^{\circ} \mathrm{C}$ and was characterized spectroscopically. Compounds 2 and 3 do not contain any $\mathrm{Ph}_{3} \mathrm{Ge}$-derived ligand. Compound 2 does not seem to be a precursor of $\mathbf{3}$ as attempts to obtain $\mathbf{3}$ by treating $\mathbf{2}$ with thiophenol in refluxing benzene for $24 \mathrm{~h}$ or in refluxing toluene for $8 \mathrm{~h}$ have failed.

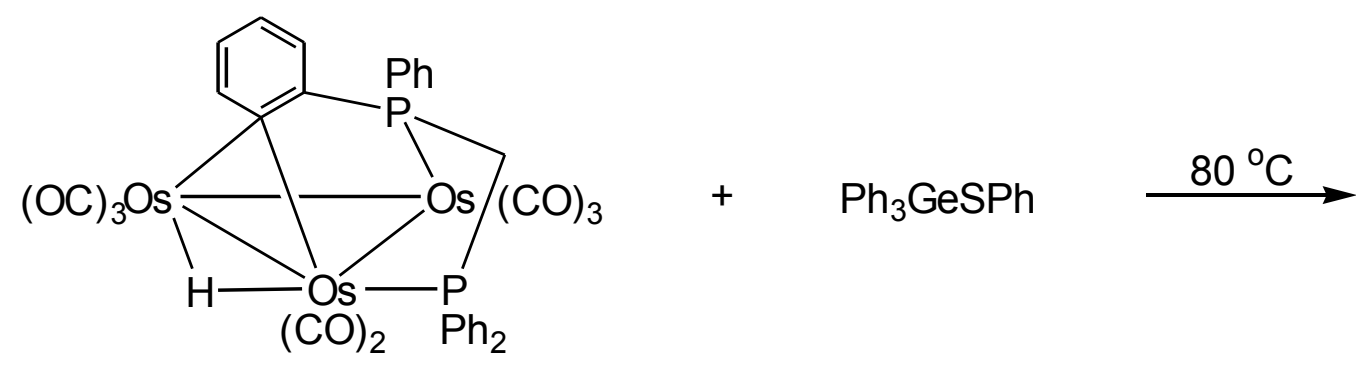

\section{1}

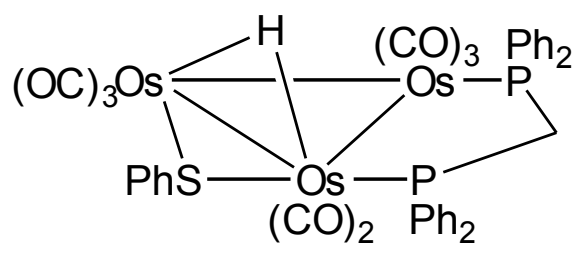

2

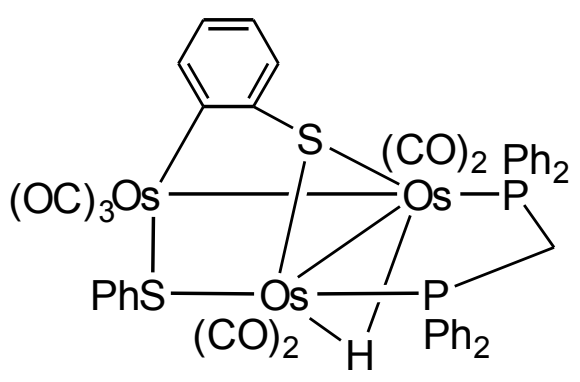

3

\section{Scheme 2.}

The solid-state molecular structure of $\mathbf{2}$ is shown in Fig. 1, crystallographic data are collected in Table 1, and selected bond lengths and angles are presented in Table 2. The structure is based upon a triangular arrangement of three osmium atoms coordinated by eight carbonyl ligands, a bridging bis(diphenylphosphino)methane (dppm) ligand, a bridging phenylsulfido ligand and a bridging hydride. The three osmium atoms define an approximate isosceles triangle of osmium atoms with one long $\{\mathrm{Os}(1)-\mathrm{Os}(2) 2.8877(5) \AA\}$ and two comparatively short bonds $\{\mathrm{Os}(1)-\mathrm{Os}(3) 2.8549(5) \AA$ and $\mathrm{Os}(2)-\mathrm{Os}(3) 2.8588(5)$ $\AA$ \}. The eight terminal carbonyl ligands are all terminal, three of which are bonded to each of Os(1) and Os(3) while the other two to Os(2). The phenylsulfido ligand spans across the Os(1)-Os(2) edge $\{\mathrm{Os}(1)-\mathrm{S}(1) \quad 2.412(2) \quad \AA \quad$ and $\mathrm{Os}(2)-\mathrm{S}(1) \quad 2.414(2) \quad \AA\}$ almost 
symmetrically with the phenyl ring perpendicullarly oriented in space with respect to the trimetallic plane. The hydride ligand is located crystallographically but not refined which also spans the Os(1)-Os(2) edge but lies on the opposite side of the $\mathrm{Os}_{3}$ plane relative to the phenylsulfido ligand. This observation is consistent with the lengthening of the Os(1)-Os(2) edge and the opening out of the carbonyl ligands along this edge $\{\mathrm{C}(1)-\mathrm{Os}(1)-\mathrm{Os}(2)$ 116.8(3) $)^{\mathrm{o}}, \mathrm{C}(4)-\mathrm{Os}(2)-\mathrm{Os}(1) 115.1(3)^{\mathrm{o}}$, and C(5)-Os(2)-Os(1) 119.7(3) $\left.{ }^{\circ}\right\}$. The dppm ligand bridges the Os(2)-Os(3) edge a little bit asymmetrically $\{\mathrm{Os}(2)-\mathrm{P}(1) 2.317(2) \AA$ and $\mathrm{Os}(3)$ $\mathrm{P}(2) 2.333(2) \AA\}$ and the phosphorus atoms of the ligand occupy equatorial site on both osmium atoms as expected. However, the Os-S and Os-P bond distances in $\mathbf{2}$ are similar to those observed in related complexes ${ }^{10-12}$ and the overall structural features are similar to the corresponding ruthenium compound $\left[\mathrm{Ru}_{3}(\mathrm{CO})_{8}(\mu-\mathrm{H})(\mu-\mathrm{SPh})(\mu-\mathrm{dppm})\right]^{28}$ and the ethanethiol analog $\left[\mathrm{Os}_{3}(\mathrm{CO})_{8}(\mu-\mathrm{H})\left(\mu-\mathrm{SC}_{2} \mathrm{H}_{5}\right)(\mu \text {-dppm) }]^{10}\right.$. The spectroscopic data of 2 are consistent with the solid-state structure and are very similar to those reported previously. ${ }^{10,}$ 27

The solid-state molecular structure of $\mathbf{3}$ is depicted in Fig. 2, crystallographic data are collected in Table 1, and selected bond lengths and angles are listed in Table 3. The molecule consists of an open triangle of three osmium atoms with two distinctly different metal-metal bonds $\{\mathrm{Os}(1)-\mathrm{Os}(2) 2.9817(10) \AA$ and Os(2)-Os(3) 2.9160(10) $\AA\}$, seven carbonyl ligands, a bridging phenylsulfido ligand, a bridging dppm ligand, a triply bridging $\mathrm{SC}_{6} \mathrm{H}_{4}$ ligand, and a bridging hydride. The carbonyl ligands are terminally bonded, two of which are boneded to each of $\operatorname{Os}(1)$ and $\operatorname{Os}(2)$ while the other three to Os(3). An interesting structural feature of $\mathbf{3}$ is the ortho $\mathrm{C}-\mathrm{H}$ bond activation of the phenyl ring of one phenylsulfido ligand thus forming a $\mu_{3}-\mathrm{SC}_{6} \mathrm{H}_{4}$ ligand on the cluster surface which spatially oriented in space such that the plane constituted by the atoms of this ligand is almost perpendicular to the $\mathrm{Os}_{3}$ plane. The covalent Os-C distance in 3 \{ Os(3)-C(12) 2.143(17) $\AA$ \} is quite similar to those observed in related complexes. ${ }^{10,12,26}$ The phenylsulfido ligand which lies on the opposite side of the $\mu_{3}-\mathrm{SC}_{6} \mathrm{H}_{4}$ ligand asymmetrically bridges the open Os(1)...Os(3) edge $\{\mathrm{Os}(1)-\mathrm{S}(2) 2.424(4) \AA$ and Os(3)-S(2) 2.459(5) $\AA\}$ through the sulfur atom while the $\mu_{3}-\mathrm{SC}_{6} \mathrm{H}_{4}$ ligand similarly spans across the $\mathrm{Os}(1)-\mathrm{Os}(2)$ bonding edge $\{\mathrm{Os}(1)-\mathrm{S}(1) 2.446(4) \AA$ and $\mathrm{Os}(2)-\mathrm{S}(1) 2.404(4) \AA\}$. The hydride ligand is located in the structural analysis but not refined which bridges the Os(1)-Os(2) bonding edge and is cis to both $\mathrm{Os}(1)-\mathrm{C}(1)$ and $\mathrm{Os}(1)-\mathrm{C}(3)$ bonds. This is also supported by the lengthening of this edge and widening of the $\mathrm{C}(1)-\mathrm{Os}(1)-\mathrm{Os}(2)$ and $\mathrm{C}(3)-\mathrm{Os}(2)-\mathrm{Os}(1)$ angles $\left\{121.6(5)^{\mathrm{o}}\right.$ and 
115.6(5 $\left.)^{\circ}\right\}$. The dppm ligand also bridges the same Os-Os edge and the Os-P bond distances are within the range reported for related compounds. ${ }^{7,10-12,26,27}$ The Os-S bond distances in $\mathbf{3}$ are also in the range found in literature. ${ }^{10-12}$ The $\mathrm{C}-\mathrm{C}$ bond lengths within the phenyl ring of the $\mu_{3}-\mathrm{SC}_{6} \mathrm{H}_{4}$ ligand fall in the range of 1.37(2) - 1.44(3) $\AA$, suggesting unperturbed benzenoid character in the ring. All other features of the molecule are within the expected range and the molecule is a 50-electron cluster with two formal metal-metal bonds assuming the phenylsulfido and $\mu_{3}-\mathrm{SC}_{6} \mathrm{H}_{4}$ ligands serve as three and four electron donor, respectively.

The spectroscopic data of $\mathbf{3}$ support the solid-state structure. The infrared spectrum exhibits absorption bands characteristic for terminally bonded carbonyl ligands. In addition to the usual aromatic resonances for the phenyl protons, the ${ }^{1} \mathrm{H}$ NMR spectrum shows a virtual triplet at $\delta-15.66(J=7.2 \mathrm{~Hz})$ for the bridging hydride ligand while the ${ }^{31} \mathrm{P}-\left\{{ }^{1} \mathrm{H}\right\}$ NMR spectrum displays two equal intensity doublets at $\delta 17.2(J=94.8 \mathrm{~Hz})$ and $21.3(J=$ $94.8 \mathrm{~Hz}$ ) due to the phosphorus atoms of the dppm ligand. The FAB mass spectrum shows the parent molecular ion peak at m/z 1370 together with fragmentation peaks due to the sequential loss of all seven carbonyl groups which are also consistent with the solid-state structure.

\section{Supplementary material}

Crystallographic data for the structures reported in this article have been deposited with the Cambridge Crystallographic Data Center as supplementary publication number (space group $P-1$ ) and (space group $P 2_{1} / n$ ). Copies of this information can be obtained free of charge on application to the Director, CCDC, 12 Union Road, Cambridge, CB2 1 EZ, UK (fax: +44-1223-336033; e-mail: deposit@ccdc.cam.ac.uk or www: http://www.ccdc.ac.uk).

\section{Acknowledgement}

AKR gratefully acknowledges the University Grants Commission of Bangladesh for a scholarship.

\section{References}


1. Collman, J. P.; Hegedus, L. S.; Norton, J. R.; Finke, R. J. Principles and Applications of Organotransition Metal Chemistry (University Science Book, Mill Valley, CA, 1987), p. 241.

2. Suss-Fink, G.; Neumann, F. in Hartley, F. R.(ed.), Chemistry of the Metal-Carbon Bond, Vol. 5 (Wiley, New York, 1989), p. 231.

3. Muetterties, E. L.; Krause, M. J. Angew. Chem. Int Ed. Engl. 1983, 22, 135.

4. Clucas, J. A.; Foster, D. F.; Harding, M. M.; Smith, A. K. J. Chem. Soc., Chem. Commun. 1984. 949.

5. Clucas, J. A.; Harding, M. M.; Smith, A. K. J. Chem. Soc., Chem. Commun. 1985, 1280.

6. Brown, M. P.; Dolby, P. A.; Harding, M. M.; Mathews, A. J.; Smith, A. K. J. Chem. Soc., Dalton trans. 1993, 1671.

7. Azam, K. A.; Hursthouse, M. B.; Islam, M. R.; Kabir, S. E.; Malik, K. M. A.; Miah, R.; Sudbrake, C.; Vahrenkamp, H. J. Chem. Soc., Dalton Trans. 1998, 1097.

8. Brown, M. P.; Dolby, P. A.; Harding, M. M.; Mathews, A. J.; Smith, A. K.; Osella, D.; Arbrun, M.; Gobetto, R.; Raithby, P. R.; Zanello, P. J. Chem. Soc., Dalton Trans. 1993, 827.

9. Harding, M. M.; Kariuki, B.; Mathews, A. J.; Smith, A. K.; Braunstein, P. J. Chem. Soc., Dalton Trans. 1994, 33.

10. Abedin, S. M. T.; Azam, K. A.; Hursthouse, M. B.; Kabir, S. E.; Malik, K. M. A.; Mottalib, M. A.; Rosenberg, E. J. Cluster Sci. 2001, 12, 5.

11. Kabir, S. E.; Malik, M. M. A.; Mollah, E.; Mottalib, M. A.; J. Organomet. Chem. 2000, 616, 157.

12. Kabir, S. E.; Johns, C. A.; Malik, K. M. A.; Mottalib, M. A.; Rosenberg, E, J. Organomet. Chem. 2001, 625, 112.

13. Kabir, S. E.; Pervin, S.; Sarker, N. C.; Yesmin, A.; Sharmin, A.; Siddiquee, T. A.; Haworth, D. T.; Bennett, D. W.; Malik, K. M. A. J. Organomet. Chem. 2003, 681, 237.

14. Kabir, S. E.; Miah, M. A.; Sarker, N. C.; Hossain, G. M. G.; Hardcastle, K. I.; Rokhsana, D.; Rosenberg. E. J. Organomet. Chem. 2005, 690, 3044.

15. Abedin, S. M. T.; Hardcastle, K. I.; Kabir, S. E.; Malik, K. M. A.; Mottalib, M. A.; Rosenberg, E.; Abedin, M. J. Organometallics 2000, 19, 5623.

16. Deeming, A. J.; Hassan, Md. M.; Kabir, S. E.; Nordlander, E.; Tocher, D. A. J. Chem. Soc., Dalton Trans. 2004, 3079. 
17. Hassan, M. R.; Hogarth, G. Hossain, G. M. G.; Kabir, S. E.; Raha, A. K.; Saha, M. S.; Tocher, D. A. Organometallics 2007, 26, 6473.

18. Kabir, S. E.; Raha, A. K.; Hassan, M. R.; Nicholson, B. K.; Rosenberg, E.; Sharmin, A.; Salassa, L. Dalton Trans. 2008, 4212.

19. Lucas, C. R. Can. J. Chem. 1986, 64, 1758.

20. SMART Version 5.628; Bruker AXS, Inc.: Madison, WI, 2003.

21. SAINT Version 6.36; Bruker AXS, Inc.: Madison, WI, 2002.

22. Sheldrick, G. SADABS Version 2.10; University of Göttingen, 2003.

23. Program XS from SHELXTL package, V. 6.12, Bruker AXS, Inc.: Madison, WI, 2001.

24. Program XL from SHELXTL package, V. 6.12, Bruker AXS, Inc.: Madison, WI, 2001.

25. A.J.C. Wilson, Ed. International Tables for X-ray Crystallography, Volume C; Kynoch, Academic Publishers: Dordrecht, 1992; Tables 6.1.1.4 (pp 500-502) and 4.2.6.8 (pp 219-222).

26. Hodge, S. R.; Johnson, B. F. G.; Lewis, J.; Raithby, P. R. J. Chem. Soc., Dalton Trans. 1987, 931.

27. Azam, K. A.; Kabir, S. E.; Miah, A.; Day, M. W.; Hardcastle, K. I.; Rosenberg, E.; Deeming, A. J. J. Organomet. Chem. 1992, 435, 157.

28. Fompeyrine, P.; Lavigne, G.; Bonnet, J. J. J. Chem. Soc., Dalton Trans. 1987, 91.

Table 1. Crystal and Structural Refinement Data for $\left[\mathrm{Os}_{3}(\mathrm{CO})_{8}(\mu-\mathrm{H})(\mu-\mathrm{SPh})(\mu\right.$-dppm) $)(2)$ and $\left[\left(\mathrm{Os}_{3}(\mathrm{CO})_{7}(\mu\right.\right.$ $\mathrm{H})(\mu-\mathrm{SPh})\left(\mu_{3}-\mathrm{SC}_{6} \mathrm{H}_{4}\right)(\mu$-dppm)] (3)

\begin{tabular}{lll}
\hline Empirical formula & $\mathrm{C}_{39} \mathrm{H}_{28} \mathrm{O}_{8} \mathrm{Os}_{3} \mathrm{P}_{2} \mathrm{~S}$ & $\mathrm{C}_{44} \mathrm{H}_{32} \mathrm{O}_{7} \mathrm{Os}_{3} \mathrm{P}_{2} \mathrm{~S}$ \\
CCDC deposit no. & $\ldots \ldots \ldots \ldots \ldots .$. & $\ldots \ldots \ldots \ldots \ldots$. \\
Formula weight & 1289.21 & 1368.35 \\
Temperature $(\mathrm{K})$ & $150(2)$ & $89(2)$ \\
Wavelength $(\AA)$ & 0.71073 & 0.71073 \\
Crystal system & Triclinic & Monoclinic \\
\hline
\end{tabular}




\begin{tabular}{|c|c|c|}
\hline Space group & $P-1$ & $P 2_{1} / n$ \\
\hline \multicolumn{3}{|l|}{ Unit cell dimensions } \\
\hline$a(\AA)$ & $11.5072(8)$ & $10.9678(2)$ \\
\hline$b(\AA)$ & $12.3475(8)$ & $28.0191(2)$ \\
\hline$c(\AA)$ & $15.1330(10)$ & $18.5013(3)$ \\
\hline$\alpha\left(^{\circ}\right)$ & $112.9460(10)$ & 90 \\
\hline$\beta\left(^{\circ}\right)$ & $91.0800(10)$ & $98.894(1)$ \\
\hline$\gamma\left({ }^{\circ}\right)$ & $106.5390(10)$ & 90 \\
\hline Volume $\left(\AA^{3}\right)$ & $1877.5(2)$ & $5105.07(14)$ \\
\hline $\mathrm{Z}$ & 2 & 4 \\
\hline Density (calculated) $\left(\mathrm{Mg} / \mathrm{m}^{3}\right)$ & 2.281 & 1.780 \\
\hline Absorption coefficient $\left(\mathrm{mm}^{-1}\right)$ & 10.320 & 7.735 \\
\hline$F(000)$ & 1200 & 2564 \\
\hline Crystal size $\left(\mathrm{mm}^{3}\right)$ & $0.44 \times 0.32 \times 0.04$ & $0.22 \times 0.10 \times 0.05$ \\
\hline$\theta$ range for data collection $\left(^{\circ}\right)$ & $2.77-28.30$ & $1.33-25.72$ \\
\hline \multirow[t]{3}{*}{ Index ranges } & $-15 \leq h \geq 15$ & $-12 \leq h \geq 12$ \\
\hline & $-16 \leq k \geq 16$ & $-33 \leq k \geq 33$ \\
\hline & $-20 \leq l \geq 20$ & $-16 \leq l \geq 22$ \\
\hline Reflections collected & 16053 & 28287 \\
\hline Independent reflections & $8500[R(\mathrm{int})=0.0295]$ & $9664[R(\mathrm{int})=0.1269]$ \\
\hline Completeness to $\theta=67.10^{\circ}$ & $96.7 \%$ & $99.3 \%$ \\
\hline Max. and min. transmission & 0.0926 and 0.6830 & 0.7014 and 0.2844 \\
\hline Refinement method & Full-matrix least-squares on $F^{2}$ & Full-matrix least-squares on $F^{2}$ \\
\hline Data/restraints/parameters & $8500 / 0 / 478$ & $6267 / 0 / 516$ \\
\hline Goodness-of-fit on $F^{2}$ & 0.933 & 1.004 \\
\hline Final $R$ indices $[I>2 \sigma(I)]$ & $R_{1}=0.0383, w R_{2}=0.1333$ & $R_{1}=0.0743, w R_{2}=0.1528$ \\
\hline$R$ indices (all data) & $R_{1}=0.0479, w R_{2}=0.1711$ & $R_{1}=0.1343, w R_{2}=0.1700$ \\
\hline Largest diff. peak and hole $\left(\mathrm{e} \AA^{-3}\right)$ & 2.3471 and -2.284 & 2.540 and -2.132 \\
\hline
\end{tabular}

Table 2. Selected Bond Distances $(\AA)$ and Angles $\left({ }^{\circ}\right)$ for $\left[\mathrm{Os}_{3}(\mathrm{CO})_{8}(\mu-\mathrm{H})(\mu\right.$-SPh $)(\mu$-dppm) $]$ (2) 


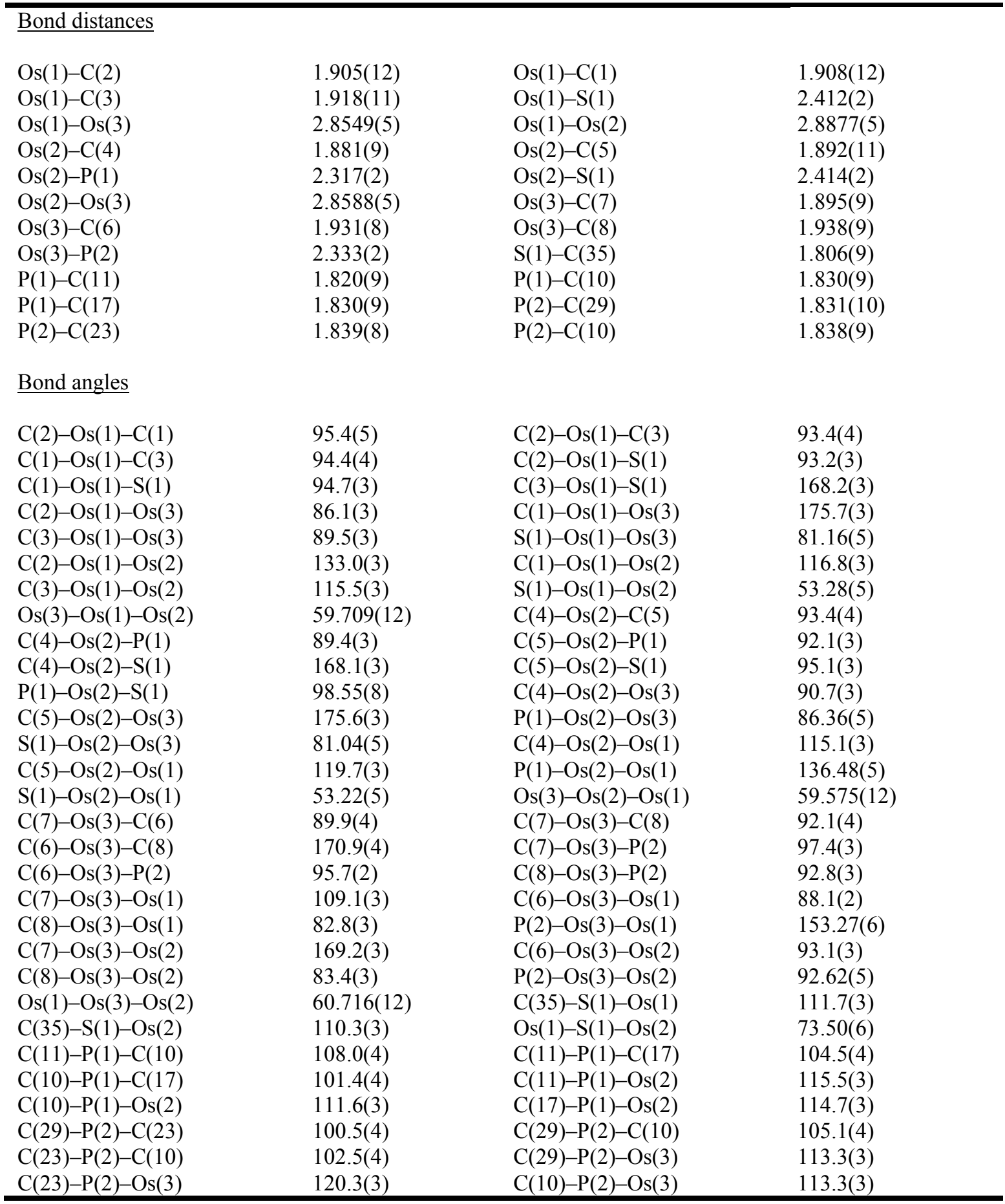

Table 3. Selected Bond Distances $(\AA)$ and Angles $\left(^{\circ}\right)$ for $\left[\left(\mathrm{Os}_{3}(\mathrm{CO})_{7}(\mu-\mathrm{H})(\mu\right.\right.$-SPh $)\left(\mu_{3}-\mathrm{SC}_{6} \mathrm{H}_{4}\right)(\mu$-dppm) $](3)$ 


\begin{tabular}{|c|c|c|c|}
\hline \multicolumn{4}{|l|}{ Bond distances } \\
\hline $\mathrm{Os}(1)-\mathrm{C}(2)$ & $1.871(17)$ & $\mathrm{Os}(3)-\mathrm{C}(6)$ & $1.88(2)$ \\
\hline $\mathrm{Os}(1)-\mathrm{C}(1)$ & $1.932(18)$ & $\mathrm{Os}(3)-\mathrm{C}(7)$ & $1.92(2)$ \\
\hline $\mathrm{Os}(1)-\mathrm{P}(1)$ & $2.349(5)$ & $\mathrm{Os}(3)-\mathrm{C}(5)$ & 1.981(19) \\
\hline $\mathrm{Os}(1)-\mathrm{S}(2)$ & $2.424(4)$ & $\mathrm{Os}(3)-\mathrm{C}(12)$ & $2.143(17)$ \\
\hline $\operatorname{Os}(1)-\mathrm{S}(1)$ & $2.446(4)$ & Os(3)-S(2) & $2.459(5)$ \\
\hline $\mathrm{Os}(1)-\mathrm{Os}(2)$ & $2.9817(10)$ & $\mathrm{P}(1)-\mathrm{C}(31)$ & $1.809(16)$ \\
\hline $\operatorname{Os}(2)-\mathrm{C}(4)$ & $1.869(18)$ & $\mathrm{P}(1)-\mathrm{C}(8)$ & $1.844(17)$ \\
\hline $\mathrm{Os}(2)-\mathrm{C}(3)$ & $1.886(17)$ & $\mathrm{P}(1)-\mathrm{C}(41)$ & $1.858(18)$ \\
\hline $\mathrm{Os}(2)-\mathrm{P}(2)$ & $2.387(5)$ & $P(2)-C(61)$ & $1.829(19)$ \\
\hline $\mathrm{Os}(2)-\mathrm{S}(1)$ & $2.404(4)$ & $\mathrm{P}(2)-\mathrm{C}(51)$ & $1.856(18)$ \\
\hline $\operatorname{Os}(2)-O s(3)$ & $2.9160(10)$ & $\mathrm{P}(2)-\mathrm{C}(8)$ & $1.845(17)$ \\
\hline \multicolumn{4}{|l|}{ Bond angles } \\
\hline $\mathrm{C}(2)-\mathrm{Os}(1)-\mathrm{C}(1)$ & $89.5(7)$ & & \\
\hline $\mathrm{C}(2)-\mathrm{Os}(1)-\mathrm{P}(1)$ & $92.2(5)$ & $\mathrm{P}(2)-\mathrm{Os}(2)-\mathrm{Os}(3)$ & $169.80(11)$ \\
\hline $\mathrm{C}(1)-\mathrm{Os}(1)-\mathrm{P}(1)$ & $93.7(5)$ & $\mathrm{S}(1)-\mathrm{Os}(2)-\mathrm{Os}(3)$ & $83.64(11)$ \\
\hline $\mathrm{C}(2)-\mathrm{Os}(1)-\mathrm{S}(2)$ & $94.4(5)$ & $\mathrm{C}(4)-\mathrm{Os}(2)-\mathrm{Os}(1)$ & $151.3(5)$ \\
\hline $\mathrm{C}(1)-\mathrm{Os}(1)-\mathrm{S}(2)$ & $88.1(5)$ & $\mathrm{C}(3)-\mathrm{Os}(2)-\mathrm{Os}(1)$ & $115.6(5)$ \\
\hline $\mathrm{P}(1)-\mathrm{Os}(1)-\mathrm{S}(2)$ & $173.12(16)$ & $\mathrm{P}(2)-\mathrm{Os}(2)-\mathrm{Os}(1)$ & $91.19(12)$ \\
\hline $\mathrm{C}(2)-\mathrm{Os}(1)-\mathrm{S}(1)$ & $97.6(5)$ & $\mathrm{S}(1)-\mathrm{Os}(2)-\mathrm{Os}(1)$ & $52.71(11)$ \\
\hline $\mathrm{C}(1)-\mathrm{Os}(1)-\mathrm{S}(1)$ & $172.8(5)$ & $\operatorname{Os}(3)-\operatorname{Os}(2)-\operatorname{Os}(1)$ & $83.70(3)$ \\
\hline $\mathrm{P}(1)-\mathrm{Os}(1)-\mathrm{S}(1)$ & $85.10(15)$ & $\mathrm{C}(6)-\mathrm{Os}(3)-\mathrm{C}(7)$ & $91.1(8)$ \\
\hline $\mathrm{S}(2)-\mathrm{Os}(1)-\mathrm{S}(1)$ & $92.25(15)$ & $\mathrm{C}(6)-\mathrm{Os}(3)-\mathrm{C}(5)$ & $98.6(7)$ \\
\hline $\mathrm{C}(2)-\mathrm{Os}(1)-\mathrm{S}(2)$ & $148.5(5)$ & $\mathrm{C}(7)-\mathrm{Os}(3)-\mathrm{C}(5)$ & $91.1(8)$ \\
\hline $\mathrm{C}(1)-\mathrm{Os}(1)-\mathrm{Os}(2)$ & $121.6(5)$ & $\mathrm{C}(6)-\mathrm{Os}(3)-\mathrm{C}(12)$ & $84.0(7)$ \\
\hline $\mathrm{P}(1)-\mathrm{Os}(1)-\mathrm{Os}(2)$ & $90.96(12)$ & $\mathrm{C}(7)-\mathrm{Os}(3)-\mathrm{C}(12)$ & $93.0(8)$ \\
\hline $\mathrm{S}(2)-\mathrm{Os}(1)-\mathrm{Os}(2)$ & $82.44(11)$ & $\mathrm{C}(5)-\mathrm{Os}(3)-\mathrm{C}(12)$ & $175.0(7)$ \\
\hline $\mathrm{S}(1)-\mathrm{Os}(1)-\mathrm{Os}(2)$ & $51.44(10)$ & $\mathrm{C}(6)-\mathrm{Os}(3)-\mathrm{S}(2)$ & $171.5(6)$ \\
\hline $\mathrm{C}(4)-\mathrm{Os}(2)-\mathrm{C}(3)$ & $92.1(7)$ & $\mathrm{C}(7)-\mathrm{Os}(3)-\mathrm{S}(2)$ & $96.3(6)$ \\
\hline $\mathrm{C}(4)-\mathrm{Os}(2)-\mathrm{P}(2)$ & $91.6(6)$ & $\mathrm{C}(5)-\mathrm{Os}(3)-\mathrm{S}(2)$ & $85.7(5)$ \\
\hline $\mathrm{C}(3)-\mathrm{Os}(2)-\mathrm{P}(2)$ & $99.6(5)$ & $\mathrm{C}(12)-\mathrm{Os}(3)-\mathrm{S}(2)$ & $91.2(5)$ \\
\hline $\mathrm{C}(4)-\mathrm{Os}(2)-\mathrm{S}(1)$ & $99.0(5)$ & $\mathrm{C}(6)-\mathrm{Os}(3)-\mathrm{Os}(2)$ & $89.5(6)$ \\
\hline $\mathrm{C}(3)-\mathrm{Os}(2)-\mathrm{S}(1)$ & $167.4(5)$ & $\mathrm{C}(7)-\mathrm{Os}(3)-\mathrm{Os}(2)$ & $179.2(6)$ \\
\hline $\mathrm{P}(2)-\mathrm{Os}(2)-\mathrm{S}(1)$ & $86.25(15)$ & $\mathrm{C}(5)-\mathrm{Os}(3)-\mathrm{Os}(2)$ & $88.2(6)$ \\
\hline $\mathrm{C}(4)-\mathrm{Os}(2)-\mathrm{Os}(3)$ & $88.7(5)$ & $\mathrm{C}(12)-\mathrm{Os}(3)-\mathrm{Os}(2)$ & $87.6(5)$ \\
\hline $\mathrm{C}(3)-\mathrm{Os}(2)-\mathrm{Os}(3)$ & $90.6(5)$ & $\mathrm{S}(2)-\mathrm{Os}(3)-\mathrm{Os}(2)$ & $83.27(10)$ \\
\hline
\end{tabular}




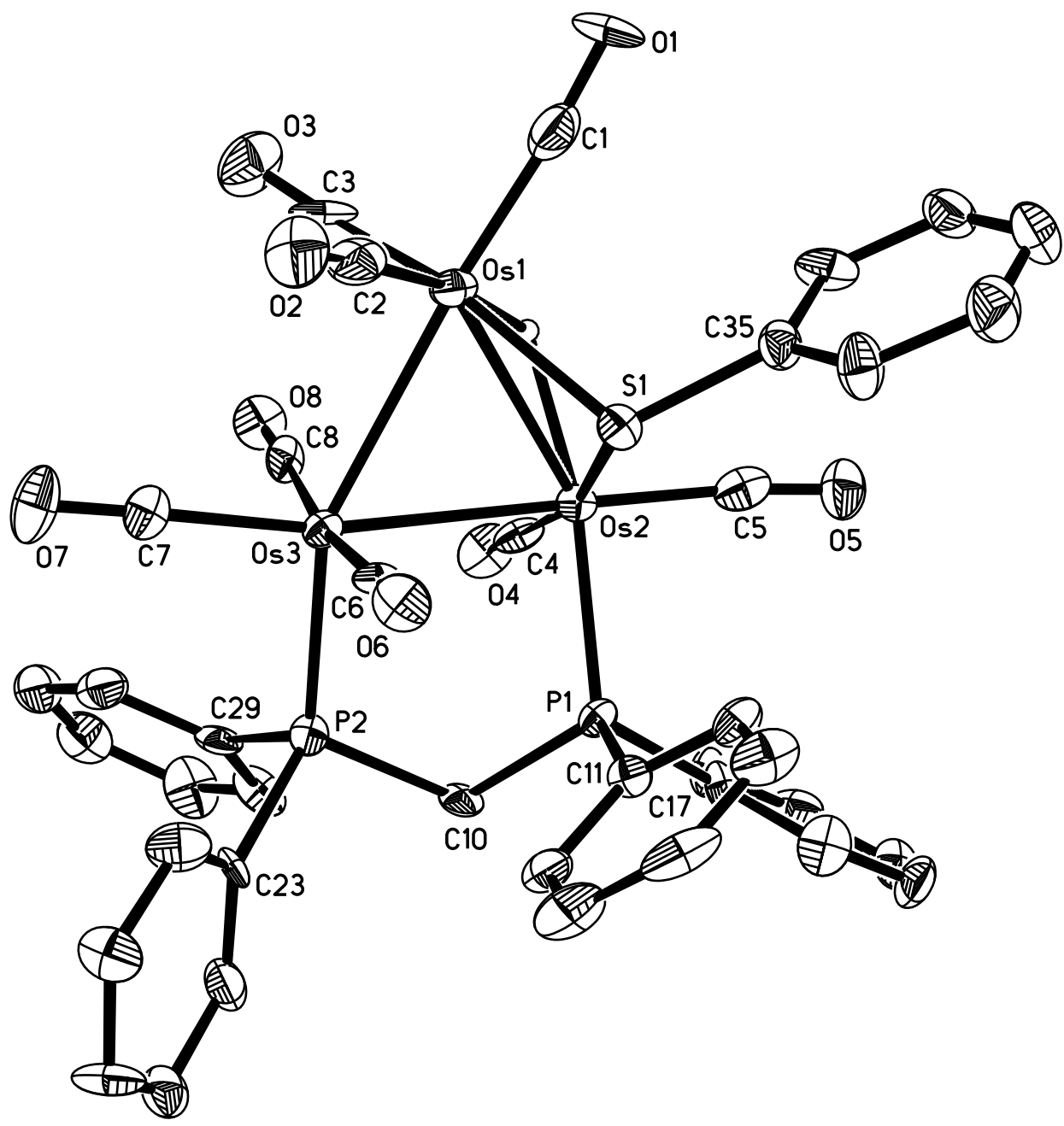

Figure 1. Molecular structure of $\left[\mathrm{Os}_{3}(\mathrm{CO})_{8}(\mu-\mathrm{H})(\mu\right.$-SPh $)(\mu$-dppm) $]$ (2) with thermal ellipsoids drawn at the $50 \%$ probability level. Ring hydrogen atoms are omitted for clarity. 


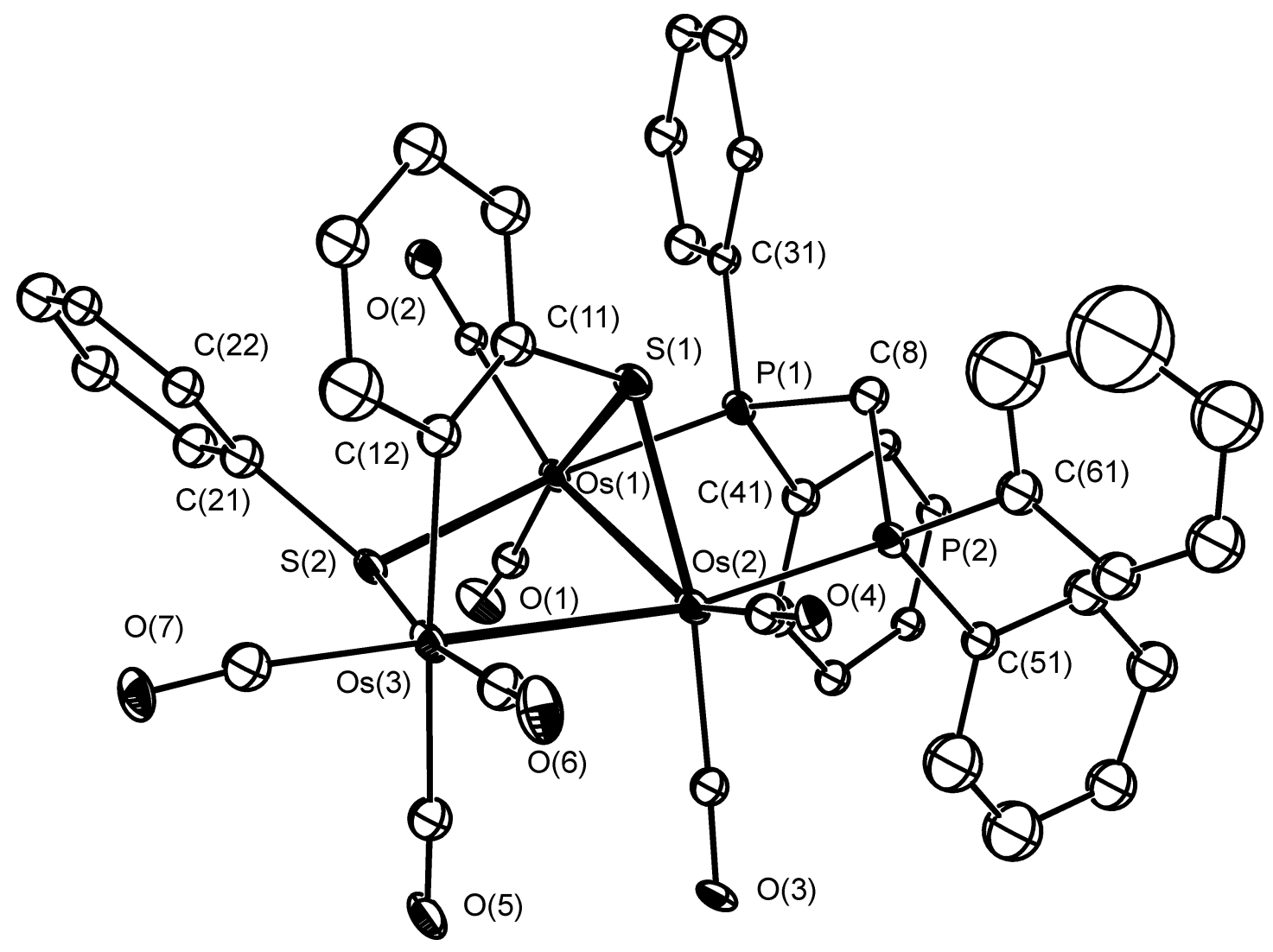

Figure 2. Molecular structure of $\left[\left(\mathrm{Os}_{3}(\mathrm{CO})_{7}(\mu-\mathrm{H})(\mu-\mathrm{SPh})\left(\mu_{3}-\mathrm{SC}_{6} \mathrm{H}_{4}\right)(\mu\right.\right.$-dppm) $)$ (3) with thermal ellipsoids drawn at the $30 \%$ probability level. Ring hydrogen atoms are omitted for clarity. 


\section{INDEX ABSTRACT}

Reaction of the electron-

Arun K. Raha,

deficient $\left[\mathrm{Os}_{3}(\mathrm{CO})_{8}(\mu-\mathrm{H})\left(\mu_{3}-\right.\right.$

$\left.\left.\mathrm{Ph}_{2} \mathrm{PCH}_{2} \mathrm{P}(\mathrm{Ph}) \mathrm{C}_{6} \mathrm{H}_{4}\right)\right]$

with $\mathrm{Ph}_{3} \mathrm{GeSPh}$ at $80{ }^{\circ} \mathrm{C}$ led

to two triosmium

compounds, $\quad\left[\mathrm{Os}_{3}(\mathrm{CO})_{8}(\mu-\right.$

$\mathrm{H})(\mu-\mathrm{SPh})(\mu$-dppm)] (2) and

$\left[\left(\mathrm{Os}_{3}(\mathrm{CO})_{7}(\mu-\mathrm{H})(\mu-\mathrm{SPh})\left(\mu_{3^{-}}\right.\right.\right.$
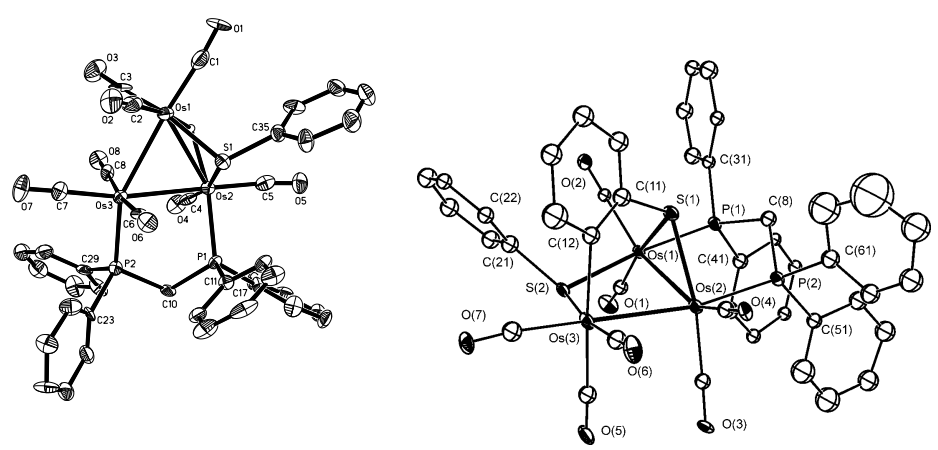

Shishir Ghosh,

Shariff E. Kabir,

Brian K. Nicholson,

Derek A. Tocher

X-ray

crystal

structures

of

$\left.\mathrm{SC}_{6} \mathrm{H}_{4}\right)(\mu$-dppm)]

$\left[\mathrm{Os}_{3}(\mathrm{CO})_{8}(\mu-\mathrm{H})(\mu-\right.$

Compound $\mathbf{3}$ represents a

$\mathrm{SPh})(\mu$-dppm)] and

rare example of triosmium $\left[\left(\mathrm{Os}_{3}(\mathrm{CO})_{7}(\mu-\mathrm{H})(\mu-\right.\right.$

complex bearing a $\mu_{3}-\mathrm{SC}_{6} \mathrm{H}_{4}$

$\mathrm{SPh})\left(\mu_{3}-\mathrm{SC}_{6} \mathrm{H}_{4}\right)(\mu-$

ligand.

dppm)] 